\title{
SUNDAY TV MASS AS A RITUAL COMMUNICATION AMONG THE YOUTH
}

\author{
Glenn Irwin Cruz Reynon \\ MA Communication Candidate, \\ The Graduate School University of Sto. Tomas \\ España, Manila Philippines \\ Program Chair, Communication \\ Angelicum College, Quezon City Philippines \\ glen_reynon@yahoo.com
}

\begin{abstract}
Sunday TV Mass (STVM) is one of the Catholic Church's initiatives for evangelization via media. Primarily produced to spread the Good News, it is specifically for the sick and physically incapable since they cannot go to churches to attend Mass and fulfill their Sunday obligation.

However, since the broadcast Mass is communicated through a mass medium and is exposed to a wider audience than necessarily targeted, some people, the adolescents (youth) in particular, make STVM an excuse to forego Mass attendance in their respective churches.

This experimental study will focus on STVM on its role as evangelizer and catalyst to ritual formation. James Carey's theory of Ritual Communication describes this practice as an enabler to the creation of a community of believers among the youth and George Gerbner's Cultivation Theory on how television 'creates' a worldview that unravels ritualistic experience by watching STVM.

The respondents of the study are 40 high school students of Angelicum College. Selected purposively, the students were instructed and monitored to watch STVM for four Sundays. These students are top achievers in their Religion subjects and are exposed to different religious activities in their school.
\end{abstract}

\section{Indexing terms/Keywords}

Sunday TV Mass, Evangelization, Ritual Communication, Cultivation, Youth

\section{Academic Discipline And Sub-Disciplines}

Communication, Cultural Studies

\section{SUBJECT CLASSIFICATION}

Ritual Communication

\section{TYPE (METHOD/APPROACH)}

Mixed Method, Cultivation Analysis, Experimental

\section{Council for Innovative Research}

Peer Review Research Publishing System

\section{Journal: Journal of Social Sciences Research}

Vol. 8, No. 2

jssreditor.cir@gmail.com

www.jssronline.com 


\section{INTRODUCTION}

It is traditional practice in the Philippines that elders take on the responsibility of honing the youth. One of the more popular "words of wisdom" reveals itself in the faithful practice of religion, so much so that it is not rare for elders to tell youngsters this perennial statement: "Linggo ngayon, minsan lang sa isang linggo kayo magsisimba."

The traditional Catholic will see to it that he fulfills his duty of going to mass at least once a week, not only because it is written in the Ten Commandments, but also because he grew up this way. One of the Church's teachings, the Sacrosanctum Concilium on Liturgy, states the "Mother Church earnestly desires that all the faithful should be led to that full, conscious, and active participation in liturgical celebrations. Hence, a mission to see to it that it is passed throughout the generations is a must for them as it is seen to be the most authentic manifestation of one's faith" (Catechism of the Catholic Church no. 1141:10).

Everything is rooted on the dominance of the influential religion in a Filipino's life. This premise may be attributed to the reliance of the Filipino on the Church's teachings on the particular pattern by which he should live his life. Part of this is the picture of God, and following what has been required by religion (in this case, attending mass every Sunday) to attain the promise of that particular religion (in Catholicism, the promise of eternal life). It maintains that complying with certain norms to attain a particular goal would necessarily enhance the meaning of one's existence - as if saying that one does not merely exist, lives and dies. In Catholicism, the Eucharist leads man to eternal life for it is a foretaste of it, and essentially a source of spiritual nourishment. As is said in Ecclesia de Eucharistia, 1:2 "For the most holy Eucharist contains the Church's entire spiritual wealth: Christ himself, our Passover and living bread. Through his own flesh, now made living and life-giving by the Holy Spirit, he offers life to men".

However, people nowadays find it difficult to keep the practice of going to church because of their busy lives, or because it does not serve them a purpose. This may be particularly true for the youth, as a substantial body of research has investigated the implications of the vast amount of attention that young people devote to media forms (Bryant \& Rockwell, 1994). This distraction by, or engagement to various media may be a major contributor to the youth's declining mass attendance.

A recent survey conducted by Social Weather Stations (SWS) on the frequency of church attendance showed the continuing decline of Catholics who attend Sunday mass: in 1991 , only $64 \%$ out of $81 \%$ Catholics in the country go to Church, and in 2013 the number further declined to 37\%. Is this decline in Sunday mass attendance a proof of the deterioration of the people's morale and sense of purpose? This peculiar query may not have its concrete answer for the time being, but the bigger concern remains: have people lost their hope in religion, or are they simply indolent and have resorted to practicing Sunday life in inertia?

To restore the practice of keeping the Sabbath, the Church has devised ways for both for nominal and practicing Catholics, whatever their circumstances may entail. Malls, for example, are now becoming places of worship for others, as regular mass celebrations are held on Sundays. The mission is to make mall-goers attend mass before their shopping which seems very relevant for most Filipinos nowadays. Even Pope Francis acknowledges the challenges of the times: in his message to Vatican Television Centre, he said "important technological challenges today are opening up ahead of us. We must not shrink from these challenges if we are firmly promoting the evangelical perspective on this global highway of communication".

Another significant measure is apparent in the emergence of Sunday TV Masses, which the Church conducts to cater to the spiritual needs of those who cannot go to church because of sickness or other preoccupations. In Communication as Culture, James Carey (1989), observed the nature of and relationship between communication, culture and technology. Carey supposed that there are forms of communication whose primary purpose is to strengthen the community by egging them to participate and share in communication or communal experiences. These are called rituals, which, in this case, are being established through STVM.

The advent of STVM is a big help for the Church to inculcate to its audience the importance of continuing Eucharistic celebrations every Sunday, as it fulfills its role as evangelizer and catalyst to ritual formation. It also fulfills Eucharisticum Mysterium, 77's teaching that says Sundays should be presented to the people as the primordial feast day, that, when assembled together, they are to hear the Word of God and take part in the Paschal Mystery.

With all these premises taken into account, the promotion of a spiritual genre through a medium the youth identifies with is looked into. This study explores if STVM can be instrumental in unraveling a ritualistic experience and cultivating faith among the youth.

\section{THEORETICAL BACKGROUND}

\section{Forming Rituals}

People rely on various media channels to meet their needs and wants nowadays (Littlejohn, 2010). In fact, it is said that the more readily available, the greater the perceived instrumentality, the more socially and culturally acceptable the use of a medium is. Andy Ruddock (2012), in his article Cultivation Analysis and Ritual Theory, said that Gerbner and Carey believed that media affected society by determining the ideas and the language that made 'society' possible. Society, being a conceived idea, is borne out of the constructions of experience from the various forms of communication technologies prevalent in the contemporary environment. This is how the power of message systems is secured: media users recreate habits, narratives and practices they have learned from mainstream media. 
In the study Mediatized Rituals: beyond manufacturing consent, Simon Cottle (2006) said mediatized ritual have much to tell about how media, from time to time, intervene in the life of contemporary societies, their contending identities and contests of interest, and can contribute to the formation of plural solidarities or 'publics'. Benjamin Burroughs' (2014) Facebook and FarmVille: A Digital Ritual Analysis of Social Gaming furthers that through digital ritual participation, networked interests, communities and lives can increasingly manifest. Nick Couldry (2002), in his study Playing for Celebrity: Big Brother as Ritual Event, said that Emile Durkheim's view on media rituals tends to celebrate all forms of ritual as fulfilling a natural need for an organic society. This shows how powerful media is - it transcends from a medium to social expectation.

Moreover, the term "ritual" embraces religious connotations. For Carey, this connection to religion emphasizes the concept of shared belief and ceremony that are fundamental to ritual view. The celebration of mass itself, for example, is a ritual as people who share the same faith come together to commemorate their belief. Repeatedly observed and practiced, this ceremony draws people towards a sense of community.

Ritual communication examines how and why people interact with communication media. It suggests that attachments to media are not simply driven by efficiency and control over media, rather, it provides constancy that individuals may find hard to attain in face-to-face relationships and other areas of everyday life (Littlejohn and Foss, 2009).

\section{Rituals as dramatization}

Ritual per se is a dramatization. It is about texts that articulate multiple aspects of cultural life, often making rites of passage or life transitions. In his article Myth, Ritual and Drama in Igboland, Ossie Enekwe (1981) talks about the relationship and similarity of ritual and theater, both being anchored on experience. He claims that both have an element of entertainment, with each easily transformable to each other as drama is the representation of an action that involves impersonation and the presence of a conscious audience (Enekwe, 1981).

Christopher Irvine (1994), in Celebrating the Eucharist: The Right Performance supports Enekwe's idea and adds that there are sufficient similarities between the business of the theatre and the worshipping assembly - both are involved in the performance of script, which is both spoken and enacted through bodily movement and gesture.

James Von Geldren (1996) however has a different point of view. In his book Bolshevik Festivals, 1917-1920, he said it is important to make essential distinctions between ritual and drama and their relationship with the stage and the audience. For one, ritual and drama use symbols differently since they address different audiences and narrate stories distinctively. Because rituals speak to a united community, it can assume that its audience has already become acquainted with its conventions. The case is not the same with drama, because it creates and defines its own conventions. By using its own language, drama addresses a larger and more diverse community that needs to identify with unfamiliar ideas.

Today, media have created and are creating their rituals. This is particularly apparent in television, as it becomes a main source of entertainment - and escape - for many. Franz-Josef Eilers (2009) notes that it is not really the content that viewers are after - but the feeling of familiarity, security, safety and protection that come from the repetitions, certain projections and frames of reference presented by the TV ritual. Eilers (2009) adds that the ritual communication model and understanding of communication is about the communicative ways and means to maintain the fiber of society: to share, participate, associate, create fellowship and enjoy common faith and convictions.

This is the very reason why Pope John Paul II advocates that the very evangelization of modern culture depends greatly on the extent of the media's influence. He explained that "it is not enough to use the media simply to spread the Christian message, it is also necessary to integrate that message into the 'new culture' created by modern communications" (Redemptoris Missio No. 37c).

\section{Religion and Ritual}

Ritual is always allied with religion.

Couldry (2005), in his book Media Rituals: Beyond Functionalism, instills that in anthropology, there are three ways to understanding rituals: habitual action, formalized action and action involving transcendent values. Ritual, as a regular action or habit (and later on involving pattern or form), gives meaning to the action towards the particular values that it embodies. This explanation, when considered vis-à-vis religion, shows how closely connected the two concepts are: participants in both ritual and religion are urged to move according to the values their practices connote.

Mathieu Deflem (1991) in his article Ritual, Anti-Structure, and Religion: A Discussion of Victor Turner's Processual Symbolic Analysis, finds Victor Turner's view on religion as "religion in action" very apt: religion is what religion does. This observation finds a perfect manifestation in the way religion is fulfilled in the Philippines. In the Southeast Asian country where around $80 \%$ of the population is Catholic (National Statistics Office, 2008), many like to predominantly express their religiosity through rituals. These religious rituals include devotions to the Black Nazarene (Quiapo, Manila), the Sto. Niño (Cebu), to Our Lady (particularly Our Lady of Perpetual Help in Baclaran) and other saints (Bautista, 2010). This representation of shared beliefs is a 'ritualization' that was passed on from generation to the other.

As is following their predecessors' lead, the Filipino youth's participation in religious rituals is quite noticeable as well. Sandoval, et. al. notes how in a 1998 Social Weather Station (SWS) survey, 87\% of the young Filipinos interviewed described themselves as religious, and $69 \%$ claimed to attend religious services at least once a week. Meanwhile, the Episcopal Commission on Youth 2003's record show that $40 \%$ of them are members of religious organizations while $15 \%$ are involved in campus-based ministries. Zimmerman (2008) notes that the 1995 World Youth Day held in Manila saw 
over four million Filipinos and delegates from other countries in attendance. The participants, especially the youth delegates, have remembered this historic event ever since.

The most recent manifestation of the youth's participation in religious rituals was apparent in Pope Francis' recent visit to the Philippines. In a Youth Encounter event held at the University of Santo Tomas, Manila, approximately 24,000 youth delegates were said to be in attendance (Rappler.com, 2014).

Ironically, however, NFO-Trends study among the Filipino youth in 2003 showed a considerable decline in the youth's involvement in religious activities. From the $84 \%$ who were actively participating in religious activities in 1995, there were only $76 \%$ in 2003 , and only $63 \%$ remained from the $69 \%$ who said they attended and took part in masses (Episcopal Commission on Youth 2003).

This may be attributed to certain rising beliefs, as Marty Macasaet (2009), in his study The Spiritual Journey of Young Filipino in Grace Leung, said that the true essence of religion seems to have been lost in a subjective, touchy-feely criterion of self-satisfaction, as young Filipinos are moving in the direction of an individual-expressive religious identity (Hornsby-Smith, 2004). In the article entitled Young People and Golden Rule Catholicism in the Philippines: The case of religiously involved Filipino students, Jayeel Cornelio (2013) echoes this and said that young Filipinos feel free to pick their beliefs and practices.

King Yoon (2011) also investigated on how audience members affect their religious knowledge, attitude and behavioral intention. In his study, Religious Media Use and Audience's Knowledge, Attitude Behaviour: The Roles of Faith Motivation, Program Appeals and Dual Information Processing, he proposed that the relationship of faith motivation and the outcomes of religious drama exposure would be mediated by the employment of the information processing strategy. His study shows that religious drama is an effective religious programming format that increases audience members' religious knowledge, religion attitude reinforcement and changes their religious behavioral intention.

The term 'ritualization' thus implies a shift in thinking about ritual. Catherine Bell $(1992,1997)$, in her articles Ritual Theory, Ritual Practice and Ritual: Perspective and Dimension, said that 'ritualization' encourages people to look at the links between ritual actions, the wider social spaces that occur in, and the particular practices, beliefs and categories that make specific ritual actions possible.

\section{The Media Today}

Innovations develop every day and people, especially the young, become more and more dependent on these. New communication networks have emerged as meaningful social exchange weakens. Technology has afforded masses the ability to connect on the macro level, yet the personal intimacy of one-on-one communication minimized (Geyer, 2009). These phenomena have undoubtedly brought nuances to the definition of ritual communication.

The younger generation feels much more comfortable in communication through social space. A study conducted by The Pew Research Center revealed that - more than half of 18 to 25 years olds have used social networking sites and more than two-thirds believe new technologies make it easier to find friends (Alsop, 2008). A research conducted by Hoe F. Khalil (2012) in Tunisia, Egypt, discussed the relationship between youth and media focusing on the way young people develop and circulate their own messages outside corporate, religious, and state instructions. As they grow up using social media to connect and communicate, it is but appropriate that youth-generated media study be introduced as a framework for analyzing these alternative forms of communications.

Peter Clarke (1971) says the most fruitful way in understanding the importance of mass communication to young people is to look at how communication fits into a context of social relationships, perceptions, and expectations. The attitude of youngsters nowadays towards the use of mass media deals with information-seeking and information-giving patterns developed by friends and family system, it is thus important to be concerned about how young people are increasingly considered as a community, if not a subculture.

Various people who have conducted different studies involving the young, media and communication share similar thoughts.

Maria Mastronardi (2003), in her study Adolescence and Media explains that it is important to explore the relationship of mass media and the young people in the context of the latter's daily lives to determine how specific media forms are constructed, deployed and consumed. Radhamany Sooryamoorthy (2011) through Communication, youth, social change and... agrees and says the consequences that media - or their use - have for the youth are worthy of in-depth investigation. With a study focused on media, communication and the young, he points out how the youth adopts and uses media to meet some immediate needs and effect constructive changes in the society. Finally, Donna Alvermann (2011) in her article Popular Culture in Traditional and New Literacies says literacy practices are changing at an unprecedented pace and speculations as to the impact of media and interactive communication technologies on current conceptions of youth's reading, writing and viewing are evident in many fronts.

\section{Media and Religion}

The Conclusions of the World Congress of Catholic Television notes that cultural change poses new anthropological scenarios. As new consumers of media demand a variety of contents where a fusion of cognitive and emotional aspects are found, it is salient to study this new "mediasphere" to determine the new relationships formed between the users and media consumption. 
In the synod of bishops, Mexican Archbishop Carlos Aguilar Retes of Tlainepantia (2012) said that young people are in the search for meaning in their lives. This makes it all the more important for the Church to be present in their worlds, since, the young might end up abandoning their search for God if the Church cannot give them the answers. He added that if the church wants to find and connect with the young, it must use the new media and gadgets that they use.

"In these young people, we see a sincere and sometimes painful search for meaning and spirituality as they bridge traditional cultural values and the excitement of the technological age with the swipe of an iPad or smartphone", Aguilar (2012) in Conclusions of the World Congress of Catholic Television (Pontifical Council for Social Communications) says.

The Philippines is by no means behind the digital curve, as life and society are likewise determined by modern means of social communication, particularly the new media. This modern marketplace becomes, especially for the young, very often the main "means of information and education, of guidance and inspiration" (Redemptoris Missio, 37c).

In effect, Pia Lansang (1986) says the youth's relationship with the liturgy should always be considered and highlights two concerns when doing so: (1) in view of the complexity of the phenomenon youth, generalizations about the young people's relationship to the Liturgy must be avoided, and (2) the main obstacle to the Liturgy is to be seen in the crisis of faith from which many young people are affected today, especially those who are extremely critical of the institutional Church.

It is thus the Church's obligation to integrate the Gospel message into various learning scenarios and moments of truth. She should also move to train and support Christians working in communication fields through proper media education.

In the Asian Synod and Social Communication, Franz-Josef Eilers (2002) noted that through Inter Mirifica's document on Social Communication of the Second Vatican Council, the Church has already declared the proper training of priests, seminarians, religious and lay people as urgent. This need is even more urgent in Asia today, as economies and the media continue to rapidly reshape societies. If the Church wants to take advantage of these modern means of social communication, she needs evangelizers who are properly trained and are professionally sound in these new means of communications.

The Church, our mother, is particularly interested in those which directly touch man's spirit and which have opened up new avenues of easy communication of all kinds of news, of ideas and orientation (Inter Mirifica, 1). STVM can actually be instrumental in reaching out to the people outside of the Church as broadcast Sunday masses share and proclaim to the world the richness of the celebration. By hearing mass, even via TV, audiences receive the Word of God and this moves them to pray.

All these premises insinuate that media and religion cannot help but co-exist practically because media is undeniably there and religion has to take advantage of the former if it wants to keep its role in people's lives. In 1975, Pope Paul VI declared "the church would feel guilty before the Lord if she did not utilize these powerful means of communication that human skill is daily rendering more perfect".

\section{STVM: Media Meets Evangelization}

The primary goal of evangelization is to put God's message as the central message (Pila, 2008, Bonnot et. al, 2001, Hendricks, 1978, Davies, 1983, Hutchings, 2010, O'Brien, 1993). In her article "What is Evangelization?", Barbara Hendricks (1978) admitted that there would be no precise definition of evangelization, but only a partial description based on one's experience of evangelizing and being evangelized. She furthered that evangelization is a process, and not an event that is accomplished once and for all. It is an on-going activity where the subject and the recipient, the evangelizer and the one to be evangelized, are both giver and receiver. Jesus is the one true initiator and enabler of evangelization, while the one who carries the message is the messenger.

William O'Brien (1993), in his article Strategies for World Evangelization, said that the Mission is the DNA of the church. It draws the whole system toward a common future: fulfilling the purpose for which it was created. He documented plans and strategies for world evangelization that may address numerous problems on lack of consensus, collaboration and comprehensiveness, and that missioning in the $21^{\text {st }}$ century confronts us with the absolute necessity to be more knowledgeable about our world and its peoples than ever before. Evangelists must (now) take into account several realities such as geography, sociography and religiography in shaping strategies.

The purpose, therefore, of all evangelizing action is to make known the person of Jesus Christ, to embody the Lord, not as some absent figure, but as a living active presence. We evangelize through the power of the gospel in which we must be rooted in our innermost selves (Hendricks, 1978).

\section{Televised Mass}

The 1963 Decree on the Media of Social Communications (Inter Mirifica No. 3) says the Catholic Church considers it one of its duties to announce the Good News of Salvation with the help of social communication media and to instruct men in their proper use.

In the US, the television set is used for almost seven hours a day (Gerbner, Gross, Morgan \& Signorielli, 1994). Locally, the National Statistics Office - Exposure of Population to Mass Media, 2008 reports that the popularity of television continued to rise in both rural and areas in the Philippines. Even though Internet use is rapidly gaining popularity among young people, television remains the dominant media form they use today.

In the study, Faith in Technology: Televangelism and the Mediation of Immediate experience, Shane Denson (2011) said that ultimate function of televangelism is not to disseminate a pre-existing (and pre-modern) message but to actively 
produce new constellations of discursive content and experience that are intrinsically tied to modernity and its technologies. He argued that faith-healing televangelism functions as a call to viewers to mount a head-on confrontation with the technological infrastructure of secular modernity, and to effect a specifically material negotiation of evangelical culture's unstable balancing between an entrenchment in and a self-marginalization from secular mainstream.

Christopher Irvine (1994) observed that regular churchgoers participate every Sunday in the Church's liturgical action, and yet their knowledge of what they are doing in their participation in the act of worship is more likely to be a tacit kind of knowing. Thus, the challenge now is to find ways of raising that understanding to a more conscious level. A challenge is posed, but does it immediately imply that TV is the answer?

Television is an unquestionably valid means for evangelization and pastoral service, which calls for professionalism and specialized training (Conclusions of the World Congress of Catholic Television). STVM is produced to help people who cannot go to Mass pray as much, since they are not really obliged to be physically present in the Church due to various reasons: sickness, inability to leave the house, the need to care for little children who cannot be left alone. Through television, they are thus united in the Eucharistic worship (Irvine, 1994).

In his article Televised Worship and Pastoral Ministry, J.G. Davies (1983) says television companies, concerned to reflect what is happening in the Churches, are now transmitting, particularly on Sundays, more and more Communion services. However, for those watching in their homes, such an act of worship may be regarded as incomplete since they cannot partake of the bread and wine. He also stated three factors have drastically modified this position: first, the emphasis upon the corporate nature of worship; second, the recognition that the sacraments are primarily actions; third, the stress upon participation.

It is important to note, however, that the televised Mass is never a substitute for the Church's pastoral care for the sick in the form of visits by parish ministers who share the Scriptures and bring Communion, nor is it ever a substitute for the Sunday Mass celebrated within a parish faith community each week (Guidelines for Televising the Liturgy, 1996). Televised Mass is a precious help for the sick and the aged prevented from joining the community in the celebration of the Eucharist. They may not be participating in the Eucharist, but they are uniting themselves with Mass as best as they could. The point to which the liturgy is moving, the climax of the event itself, is the moment when television viewers are left most stranded and aware of their isolation (Davies, 1983).

The STVM also caters to people without priests and who view the mass as the best possible thing to hear the Word of God to pray, listen and be nourished. This also serves as a special opportunity for them to listen to the homily. Priests and bishops alike are given the chance to give their homilies a little more focus and effectively in the Word of God through televised masses. Even though people are at home, they can unite themselves and pray and be inspired by looking at the rituals, listening to the prayers and readings and being in communion in the holy Mass.

The application of all these to televised communication services at the present day is relatively simple since what is to be proposed could be regarded both as a continuation of the practice of the early Church and an extension or addition to the pastoral ministry already being exercised in the form of home celebrations or of communion from the reserved species (Davies, 1983).

In Italy, Davide Zordan's (2014) Screening Piety, Invoking Fervour: The Strange Case of Italy's Televised Mass discussed the television broadcasting of Catholic Masses today from an interdisciplinary perspective that integrates theology with religion, media studies and television studies. His paper analyzes the unique success and "proliferation" of televised Masses in the country. Zordan (2014) concluded his paper with a reflection on the specificity of (televised) Mass as a ritual action.

The broadcast of Mass continues to be one of the most widely followed programs of Catholic television channels (Conclusions of the World Congress of Catholic Television), thus complying to Communio et Progressio no. 4's teaching of adding a new dimension to social intercourse as evangelization continues to make use of mass media. Vast numbers of people then get the chance to share in the life and progress of the community. Television itself may cater to needs that religion used to satisfy while presenting attractions and gratifications that counter some religious beliefs and absorb others in its broad and popular mainstream (Gerbner, et. al, 1984).

Religion and Television: A research report by George Gerbner, et. al (1984) probed how the "electronic church", particularly the television ministries, express a fairly stable, coherent and conservative world view that serve more to rally believers than to recruit or convert others. According to their study, watching television is an expression of belief and an experience that is not inconsistent with and may even compliment local church attendance and contribution.

However, it should be explained well that watching Mass on TV is not an excuse to forego Mass attendance in Churches, since a TV Mass does not fulfill the Sunday obligation of a viewer. It is unfortunate that some people who are neither disabled nor sick opt to just watch TV Mass on Sundays for its convenience. They fail to understand that to be considered as participants, physical presence where the Eucharist is being celebrated is required. Being there is necessary if we are to join in the sacramental encounter with the Lord.

The Mass is televised or broadcast, but local ordinaries must see to it that prayer and participation of the faithful do not suffer (Eucharisticum Mysterium, 72). 


\section{Findings}

Today's youth is influenced a lot by media. Admittedly spending an average of one to two hours daily in front of the television, the way they think, act and even speak are easily influenced by the programs they follow.

Majority of this study's respondents are active TV viewers who watch programs daily staring from the 6:00pm primetime block up to the station sign-off. Despite the differences in program preferences in varying time slots, the primary reasons for utilizing the television are similar: to be entertained, to escape from real life, albeit temporary, and to unwind.

This study anchors on the youth's affinity to television - and shows how mass media is instrumental in the evangelization and proclamation of the Good News. Sunday TV masses, thus, fulfill the objective of proclaiming the Word of God in every Filipino home throughout the world. The Church's use of a mass medium to promote the liturgy and build a community of the faithful proves that She is taking advantage of modern means of communication to further her cause.

STVM's existence thus provides the faithful at least a glimpse of the richness of the Holy Eucharist - and though it does not fulfill the duty of a Sunday worship in church - it invites the viewers to sincere prayer and devotion.

The practice of attending mass every Sunday is not just an obligation to God. More than an obligation, it is a tradition, especially in a dominantly Catholic country like the Philippines. The elders, by accompanying the young when hearing mass, have gradually developed this habit among them. And they have succeeded in eliciting a positive effect: the youth is aware of the importance and essence of hearing mass on Sundays, as manifested by the respondents' $100 \%$ preference of attending mass in their respective parishes on Sundays. When physically present in the church, they claim to not only feel God's presence more, but also blessed, holy and fulfilled. Moreover, 36 of the 37 survey participants agree that STVM aids in the Church's mission to evangelize.

The STVM, however, is not intended for the youth as it specifically targets the old, the disabled and the sick. Despite this condition, it is incorrect to say that the STVM is irrelevant to the youth, especially when they are most exposed to the most popular mass medium. Majority of the respondents see the need for Sunday TV Mass as it ushers the growth of faith through evangelization and catechesis.

\section{CONCLUSION}

The Church is continuously finding ways to keep people in religious attendance to masses, and STVM provides an avenue to pursue this mission. As STVM is a promising ritual that can and will invite the youth to be physically present in the celebration of masses, it fulfills the passing on of the religious ritual from generation to generation.

Data cited by the studies above show that religion occupies a vital role in inculcating values to young Filipinos. Through the absorption to media use as ritual, viewers develop a habitual consumption and utility of media aimed at involving themselves in the celebrations - case in point: none of the popular religious events that the Filipino observes would have been communicated well in the absence of media.

This brings to focus how media, or television in this case, successfully creates a worldview that becomes the reality because people believe it to be so (Baran and Davis, 2012). Rituals are thus developed as certain beliefs and practices are cultivated in the minds of its viewers through repeated exposure.

The combined effect for massive television exposure by viewers over time subtly shapes the perception of social reality for individuals and, ultimately, for our culture as a whole. Gerbner (1998) adds that mass media cultivate attitudes and values that are already present in a culture; it maintains and propagates these values among the members of the culture, thus binding its members together.

And yes, it encourages even the individual-expressive religious to be actively participating in the spiritual experience, because STVM is not a substitute for the participation in Eucharistic services, but an aid to develop practicing (over nominal) Catholics.

With the current shift from physical to virtual communication, STVM schemes to establish new community believers who take part in the ritual. It also leads people to understand the value of being physically present in the mass. STVM can eventually prove to be instrumental in the merger of a ritual and its physical community. This furthers that STVM as a ritual, addresses the Church's need to adapt to the demands of society's ever-changing landscape.

Everything, indeed, is rooted on the dominance of the influential religion in a Filipino's life.

\section{ACKNOWLEDGEMENT}

The author would like to thank Prof. Alice Villadolid, Dr. Joyce Arriola, Dr. Rosanni del Mundo and Miss Jessa Ericka Bien for making this research possible.

\section{REFERENCES}

1. Alvermann, D. E. (2011) Popular culture and literacy practices.In M. L. Kamil, P.D. Pearson, E. B. Moje. \& P. P. Afflerbach (eds.), Handbook of Reading Research: Volume IV. New York: Routledge/Taylor \& Francis Group

2. Alsop, R. (2008) The trophy kids grow up: How the millennial generation is shaking up the workplace. San Francisco: Josey-Bass

3. Barran, S. \& Davis D. (2010) Mass Communication Theory, $6^{\text {th }}$ Edition. Wadsworth Cengage Learning 
4. Bautista, Julius (2010) Church and State in the Philippines: tackling life issues in a "Culture of Death", SOUJOURN: Journal of Social Issues in Southeast Asia, (25)1

5. Bell, Catherine (1997) Ritual: Perspectives and Dimensions. New York: Oxford University Press.

6. Bonnot, B. et. al, (2001) A liturgical via media. America Press Inc.

7. Bryant, J. \& Rockwell S. C. (1994) Effects of Massive exposure to sexually oriented prime-time television programming on adolescents' moral judgment. In D. Sillman, J. Bryant, \& A.C. Huston (eds.), Media, Children, and the family: Social, scientific, psychodynamic, and clinical perspectives. Hillsdale, NJ: Lawrence Erlbaum.

8. Burroughs, Benjamin (2014) Facebook and Farmville: A Digital Ritual Analysis of Social Gaming. USA: University of lowa

9. Carey, J. (1975a) "Culture and Communications."CommunicationResearch, 2: 173.191.Carey, J. (1975b) Sociology and Public Affairs: The Chicago School. Beverly Hills, CA: Sage.

10. Clarke, Peter (1971) Introduction: Some Proposals for Continuing research on Youth and the Mass Media. American Behavioral Scientist 14:313

11. Cornelio, Jayeel (2013) Young People and Golden Rule Catholicism in the Philippines: The case of religiously involved Filipino students. In Giselle Vincett, ed., Christianity in the Modern World: Changes and Controversies. Aldershot: Ashgate.

12. Cottle, Simon (2006) Mediatized rituals: beyond manufacturing consent. UK: Cardiff University

13. Couldry, Nick (2002) 'Playing for Celebrity: Big Brother as Ritual Event', Television \& New Media 3-3: $283-95$.

14. Davies, J. (1983) Televised Worship and the Pastoral Ministry. Theology. 86:259

15. Deflem, Mathieu (1988) Processual symbolic analysis in the writings of Victor W. Turner, M.A dies. The University of Hull, England

16. Denson, Shane (2011) Faith in Technology: Televangelism and the Mediation of Immediate Experience. Phenomenology and Practice, Vol. 5. No. 2 American Studies. Leibniz Universitat Hannover

17. Durkheim, E. (1965) The Elementary Forms of Religious Life. New York: Free Press.

18. Eilers, F. (2009) Communicating in community. Manila: Logos (Divine Word) Publications, Inc.

19. Eilers, F. (2009) Communicating in Ministry and Mission. Manila: Logos (Divine Word) Publications , Inc. Third Edition

20. Eilers, F. (2009) Communicating Church: Social Communication Documents. Manila: Logos (Divine Word) Publications, Inc. Fourth Edition

21. Enekwe, Ossie (1981). 'Myth, Ritual and Drama of Igbo Rituals' in Drama and Theatre in Nigeria: A Critical Source Book. Ogunbiyi, Yemi ed. Bath: The Pitman Press

22. Episcopal Commission on Youth (2003) The National Filipino Catholic Youth Survey 2002, Manila: Catholic Bishops' Conference of the Philippines

23. Geldern, James von (1993) Bolshevik Festivals, 1917-1920. The Regents of the University of California. University of California Press.

24. Gerbner, G., Gross, L., Morgan, M., \&Signorielli, N. (1994) Growing up with television: The cultivation perspective. In J. Bryant \& D. Zillbaan (Eds.) Media effects: Advances in theory and research. Hillsdale, NJ: Lawrence Erlbaum.

25. Geyer, V., et al (2009) Roundtable Discussion Examining Ritual, technology, and Community in Urban Communication. Proceedings of the New York State Communication Association: Vol, 2009 Article 3.

26. Guidelines for Televising the Liturgy. www.usccb.org/ prayer-and-worship/the-mass/frequently-asked questions/guidelines-for-televising-the-liturgy.cfm.

27. Hendricks, B. (1978) What is Evangelization? Missiology: An International Review. 6: 409-424

28. Hendricks, B. (1993) Book Review: The New Catholic Evangelization. Missiology: An Review. 21: 360

29. Hornsby-Smith, Michael (2004) 'The Changing Identity of Catholics in England', in Simon Coleman and Peter Collins (eds.) Religion, Identity and Change: Perspective on Global Transformations, Aldershot, UK: Ashgate

30. Hutchings, T. (2010) The Internet and the Church: An Introduction. The Expository Times. 122:11-19

31. Irvine, C. (1994) Celebrating the Eucharist: A Rite Performance. Theology 97:256

32. Khalil, J. (2012) Youth-Generated Media: A Case of Blogging and Arab Youth Cultural Politics. Television \& New Media 14:338

33. Lansang, P., O.S. B., 1986. The Thematic Eucharistic celebration for youth. (Master's Thesis, Graduate School of Liturgy, San Beda College, 1985)

34. Littlejohn, S., (2010) Theories of Human Communication. Belmont, CA: Wadsworth Publication.

35. Macasaet, Marty (2009) 'The Spiritual Journey of Young Filipinos' in Grace Leung (ed.), The Y Factor: 2009 Yearbook on the Filipino Youth. Makati: Salesian Missions

36. Mangahas, Mahar, et al (2013) 9\% of Catholics Sometimes Think of Leaving the Church. Quezon City: Social weather Stations Institute

37. Mastronardi, M. (2003) Adolescence and Media. Journal of Language \& Social Psychology. 22:83

38. McNamara, E., (2005) An article discussing Televised Masses. Zenit International News Agency.

39. National Statistics Office, Philippines in Figures 2008, Manila: National Statistics Office

40. National Statistics Office, Exposure of Population to Mass Media 2008, Manila: National Statistics Office

41. NFO-Trends, Ateneo Youth Study 2001 Quezon City: Global Filipino Foundation; The Philippine Province of the Society of Jesus; The Grade 7 Parents' Council (1998-1999) of the Ateneo de Manila Grade School

42. O'Brien, W. (1993) Strategies for World Evangelization. Review \& Expositor. 90: 43-52 
43. Pila, A., 2006. The significance of the instruments of social communication: towards a training program at the immaculate conception major seminary (Master's Thesis, Graduate School of Theology, Immaculate Conception Major Seminary, 2005).

44. Ruddock, A. (2012) Youth and Media. Cultivation Analysis and Ritual Theory. Australia: Monash University

45. Sandoval, Gerardo A., et al (1998) The Situation of Filipino Youth: a National Survey. Quezon City: Social weather Stations Institute

46. Sooryamoorthy, Radhamanny (2009) Communication, youth, social change and...International Sociology Review of Books. Sage Publication.

47. Thomas, P. (2009) Selling God/saving souls: Religious commodities, spiritual markets and the media. Global Media and Communication. 5: 57-76

48. Tucher, Andie (2007) Communication, Community, Reality, Ritual, and the "Potato Hole" Woodson. Journal of Communication Inquiry. Sage Publications.

49. Von Geldern, James. Bolshevik Festivals, 1917-1920. Berkeley: University of California Press, c1993 1993. http://ark.collib.org/ark:/13030/ft467nb2w4/

50. Wooden, C. (2012) For Synods members, media part of the problem, part of the solution. Catholic News Services. http://ncronline.org/news/vatican/synod-members-media-part-problem-part-solution

51. Yoon, Kisung (2011) Religious Media Use and Audience's Knowledge, Attitude, and Behaviour: The Roles of Faith Motivation, Program Appeals, and Dual Information Processing

52. Zimmerman, Carol (2008) 'Fewer Youths Will Attend World Youth Day than Previous Years' American Catholic Online. Retrieved from: http://www.americancatholic.org/News/WYD2008/feweryouths.

53. asp.

54. Zordan, D. (2014) Screening Piety, Invoking Fervour: The Strange Case of Italy's Televised Mass. Journal of Religion, Media \& Digital Culture.56

55. (1993) "Sharing Good News with the Poor": World Evangelical Fellowship Theological Commission Summary of the Findings of a Consultation at New Delhi on "The Evangelization of the Poor". Transformation: An International Journal of Holistic Mission Studies. 11:12 